\title{
HISTORICAL DIMENSION OF THE RAILWAY NETWORK, ITS ECONOMIC AND URBAN IMPACT IN SAN JOSÉ DE CÚCUTA
}

\section{DIMENSIÓN HISTÓRICA DE LA RED FERROVIARIA, SU IMPACTO ECONÓMICO Y URBANO EN SAN JOSÉ DE CÚCUTA}

Mawency Vergel Ortega'

Julio Alfredo Delgado Rojas ${ }^{2}$

Yannette Díaz Umaña ${ }^{3}$

UFPS

\section{ABSTRACT}

The research aims to analyse the process of coverage of the railway network from England to San José de Cúcuta - Colombia, its impact as a transport system in the urban configuration.

1 , Postdoctora en Imaginarios y representaciones sociales, Doctora en Educación, Docente investigador, Filiación: Universidad Francisco de Paula Santander. Correo electrónico: mawency@ufps.edu.co. Orcid: https://orcid. org/0000-0001-8285-2968

2 Magister en Educación Matemática, Arquitecto, Docente investigador, Filiación: Universidad Francisco de Paula Santander. Correo electrónico: julioalfredo@ufps.edu. co. Orcid: https://orcid.org/0000-0001-6944-832X

3 Magister en Gestión Urbana, Arquitecta, Docente investigador, Filiación: Universidad Francisco de Paula Santander. Correo electrónico: yannettedu@ufps.edu.co . Orcid: https://orcid.org/0000-0002-1888-7995
The research follows a qualitative approach from documentary analysis, which explores the historical particularities that make this process a significant event in the history of Colombia and the city of Cúcuta and quantitative by analysing mathematical models in productivity. It is concluded that the railway allowed the commercial exchange and development of the region, achieving its highest productivity in the thirties, and initiates a potential decline in the forties. 


\section{RESUMEN.}

La investigación tiene como objetivo analizar el proceso de cobertura de la red ferroviaria desde Inglaterra hasta San José de Cúcuta - Colombia, su impacto como sistema de transporte en la configuración urbana. La investigación sigue un enfoque cualitativo a partir del análisis documental, que explora las particularidades históricas que hacen de este proceso un Se concluye que el ferrocarril permitió el intercambio comercial y el desarrollo de la región, alcanzando su mayor productividad en los años treinta, e inicia un potencial declive en los años cuarenta.

\section{INTRODUCTION}

In response to the demands of competitiveness in a context of openness and internationalization of the Means of transport have been an instrument of development in the evolution of the world. The railway was one of the greatest inventions of the industrial revolution [1], whose technological model was replicated, successfully adapting to different geographies, impacting both rural and urban scenarios, as well as the economy, politics and socio-cultural aspects of humanity, hence this research seeks to answer questions about the historical dimension of the railway network, its economic and urban impact in San José de Cúcuta-Colombia.

As far as the methodological framework is concerned, the present study considered carrying out a mixed descriptive analysis based on the documentary compilation, which formulates the need, when the phenomenon to be investigated is historical, to formalize a theoretical compilation that favors the reconstruction of the facts [2]. On the other hand, also, in addition to the qualitative approach, it makes use of quantitative research with deductive method with predictive correlational designs [3], to establish the investment of the State and the coverage thereof, which determine the variance of one or more variables based on the variance of other variable(s). As with experimental models, the study variables are classified as independent (predictive) and dependent (outcome). However, these variables are not manipulated, as they occur naturally [4].

\section{METHODOLOGY}

The study was framed in the qualitative approach [5], supported by a field study, documentary following a correlational level [3], which, based on different conceptions, is developed through stages such as diagnosis of needs, approach and theoretical foundation of proposals, methodological procedure, activities and resources necessary for its execution and analysis of economic, financial and social viability, and its implementation [6]. A systematic methodology is followed for the treatment of information sources, which would offer an organized and coherent strategy of search and analysis, in favor of the realization of a critical synthesis. In agreement, building a particular document review and analysis methodology for the state of the art was projected as the base input to confront the circumscribed research commitment, where the processes of interpretation, critique and argumentation were the pillars to facilitate the creation of inferences and relationships [7]; systematization has been understood and approached as a path of recovery, analysis and appropriation of the educational practices of the academic program that, by relating its theoretical and practical components systemically and historically, makes it possible to understand and explain the contexts. As documentary research, the state of the art is guided by several principles that give rigor to its development, as follows: i) purpose. It represents the commitment to establish previous research objectives; ii) coherence. It is to have internal unity in terms of phases, activities and data; iii) Loyalty. It refers to support in terms of collection and transcription; iv) Integration. It implies articulation and global evaluation of 
the process and iv) Understanding. It translates into favoring theoretical construction over the object of study [8]. With regard to the procedural aspect and, in particular, to go after the historical footprint of the railway, the foundations of the state of the art in terms of its macro development phases were taken as a basis: heuristics or the collection of sources of information and hermeneutics or analysis. The heuristic phase, of preparatory order, represents the procedure of search and compilation of information sources according to their nature and characteristics; it is the approach to the object of study, through the delimitation and definition of particular search strategies [9]. In order to respond to this interest, the development of the hermeneutic phase was based on the foundations of the critical qualitative analysis approach which, as a positioned strategy, has given "categorization" its corresponding level in research. In correspondence, the process of analysis was supported in the approaches of Strauss and Corbin [10], in particular, approaches on the founded theory [11]; theory that allows to contextualize and reveal the interactions and constructions. the protocol of revision includes norms of revision from the diagnosis of works, texts, revision of sources of investigation, registry of experiences of people [12]; it includes criteria of exclusion of publications with designs that distance from the approach of systematization and criteria of inclusion with topics of processes of approach of the problem roles, elements considered axes in the historical becoming of the tram, were topics the analysis, the deconstruction, interpretation, articulation, design and use of means, construction of categories and production. A final phase includes the strategy of extracting data from the document review format structured on completion data, descriptive data, relevant topic, quantitative data of production and investment and the valuation.

The second phase of the methodology, comprising measurement, consists of characterizing the process by identifying mathematical models and the parameters (input variables) [13] that affect the predictive model of investment I for a time $t$, corresponding to a function and the correlation between variables. In the third stage, analysis, the team analyzes current and historical results data.

\section{RESULTS}

The analysis documental shows from history and evolution of the railway network of the railway network in the world goes back to England around 1825 [14], when the first locomotive crosses the London urban landscape, an event typical of the industrial revolution, initiated by the invention of the steam engine patented by the Scottish engineer James Watt. Nieto affirms that the iron infrastructure would take from this moment, between three and four decades to extend and to be possessed, bearing in mind that the initiative of the steam locomotive developed by Richard Trevithick in 1804, represents admiration for the rapid coverage, since for 1840 it was reached $7250 \mathrm{~km}$ of railway network between Liverpool and Manchester [15], this vertiginous expansion of the system, supposed not only a powerful urban impact of modernization in England, but also the conception of a replicable model that spread quickly in Europe and with certain difficulties, that did not stop being profits, in Latin America.

In this sense the construction of railroads in Latin America during the XIX century constituted the most expensive technological import, therefore, the imminent indebtedness of the governments to the industrial powers, especially England [16]. This same author highlights the Cuban case, building narrow gauge railroads, because before the War of the Ten years (1868 - 1878), already extended more than 1200 kilometres of railway network, which meant, for a true milestone from the territorial and urban point of view, alleviating the communication between the productive 
zones of the interior with the export ports [17]. This infrastructure, of international origin, figured for Cuba as a revolutionary transformation in terms of connectivity and infrastructure, but also with a high economic impact.

The Development of the railroad network in Colombia, experience occurred in 1837, must pass more than 13 years, so that in 1850 the railroad is inaugurated in Panama [16]. Explaining the process Nieto, refers to the railroad law issued by Congress in 1836 [18], which regulates a series of privileges and royalties to natural and legal persons who build and operate a line between Panama City and the navigable area of the Chagres River, thus communicating the Atlantic and Pacific oceans. This proposal achieved its objective endorsed by law 4 of July of 1850 , accrediting the hiring of the railroad as this author informs it, from there the formal implementation of this system of transport was undertaken, contracting for the construction of the railroad lines, an English company and the Civil Engineer Francisco Javier Cisneros, reaching for the year 1885, 236 constructed $\mathrm{km}$ of railroad line. Later, in 1871, the fifteenkilometre-long railway, built on flat land in Barranquilla with the port of Sabanilla, was inaugurated [19]. This reveals the late and slow way in which the railroads were implemented in Colombia, mainly due to the topographical and geographical conditions of the country, the lack of economic resources, the precarious development plan of the transport infrastructure, the territorial dispersion of the population, which made the construction of this transport system a difficult and costly task [19].

It also compares rail development in Colombia with other Latin American countries that had anticipated its construction, such as Brazil, which already had more than 2,000 kilometers of railroads in 1871, and Mexico with more than 1600 kilometers. All this in order to objectively show the panorama, so they interpret that between 1850 and 1900 reached 0.15 kilometers of railroads per thousand inhabitants in Colombia, well below the average of the rest of Latin American countries, which concludes the poor performance in the construction of railroads in the country On the other hand, the young republic and political changes in Colombia, did not generate the best environment for the rapid momentum of this rail project in the country, so it stands out the mark of the conformation of the Republic, of a political project that tried to relate adequately a varied geographical and cultural territory; for this reason, it carries in its very structure the idea of this nation, and in its evolution, the very history of Colombia, full of improvisation, narrowness and disorder. In that measure, its permanence demands a process of remembrance and re-signification, under penalty of total destruction [20] alluding to Colombian railway heritage. However, the networks reached a coverage of 126 municipalities, crossing the irregular relief of the three mountain ranges, through this transport system, which was multimodal articulated with navigation in some rivers and the precarious road network in Colombia [21].

The case of San José de Cúcuta, presents as antecedent the earthquake of 1875 , that marks a point of departure, by the conditions of undertaking of the city. The Secretary of the Interior describes that, at the time of the incident, the city had certain advantages that promoted it economically and culturally, so there was already a maritime insurance company, a savings bank, one of the largest marketplaces roofed, warehouses and warehouses of dynamic commerce, eleven schools with 845 students, a theater concurred, to later be left in ruins after the earthquake [12]. This incident exhorted to rebuild the city giving transcendence to the project of the railroad, as Caicedo prints it when labeling: "Being Colombia the first nation in South America in integrating its railroads internationally and Cúcuta the first Colombian city in the use of 
the tramway for passengers traffic" [18]. which means the privilege of being strategically located on the border in order to confer this distinctive feature on it at that time, despite not embodying the first Colombian case in having its own railway system, in such a way that the inauguration of the first station took place on June 30, 1888. The truth is that this new means of transport was integrated with the export and import of national agricultural products, so that on September 13, 1924 a binational agreement was authorized to connect Colombia and Venezuela generating a commercial connection [17]. It also alludes to indicators that were potentialized with the help of the railway line in 200000 loads of coffee were transported by railroad and 150000 of cocoa that were exported annually following the route of the station Cúcuta to Villamizar port [22]. In this sense it should be noted that the main stimulus to economic growth in Colombia in the first half of the twentieth century was the rapid expansion of coffee remittances [23], representing $51.2 \%$ of total exports in 1920 , increasing to $77.8 \%$ in 1950 [22].

These data explain in some way the strategic convenience of the construction of the railroad, linking it as a special center of world connection that covered the route from Maracaibo to Coro and that later, were transferred to small ships that made the transshipment to the transatlantic in Curacao, La Guajira and Puerto Cabello, which sailed to New York and Europe [16]. Therefore, the idea of a city with an international connection generated great expectations for its potential regional and international connectivity [22]. Considering this perspective, the connection of the railway system with the Venezuelan system to have access to the sea through the Gulf of Maracaibo was hierarchized as announced earlier, and for this it was necessary to think about several lines: the stretch between Cúcuta and Puerto Villamizar to the north, a second stretch that looked for San Antonio del Táchira to the east, and later the south line to Pamplona
[21]. Part of the main role of the railroad was to promote trade and production for export, hence its mode for cargo, as happened in other regions of Colombia. However, Cúcuta did not abandon the solution of internal needs and micro markets, paying attention to the transport of people as was done with the tram. Even so, the political situation led to some of these projects not being satisfactorily completed or operating partially with respect to the original design.

Not only did the political environment cause difficulties, understanding the postindependence period, and the destabilization with the Thousand Days War, but also the precarious health conditions of the area made it difficult to build the railway system in the city. Arias says that despite the adequacy of mobile hospitals, malaria and other tropical diseases caused the death of workers and engineer Manuel Serrano [23]. Another situation related to the hard work was the need to mobilize numerous prison workers for those days, these practices lasted in Cúcuta for some time [24]. In any case, the construction was paused, since only an annual average of five kilometers was completed, even so, a decline in the coverage of the lines is recognized, in such a way that by the year $194032 \mathrm{~km}$ of the total achieved a decade before had been lost. This situation is related to the authorization of the Municipal Council to the engineer José Faccini in 1941 [22], to raise part of the rails of the tram and of the railway line, and with it to pave to enable the vehicular traffic, giving opening with the time, to the definitive closing of the line in 1960 [23]. In other words, both Meisel, Ramírez and Jaramillo [21], as well as Correa [22], admit to justifying state errors in the contractual, administrative and areas management, as factors that determined the decline of the railway, but not before stressing that the investment made in railways in the twenties was profitable, focusing on the problem of prolonging the operation after the forties, when the transport system had ceased to be lucrative. 
There were many difficulties to develop the railway system in San José de Cúcuta, however, the railways allowed regional and binational connection, consolidating as a city. The relationship of the railway system with industry, agricultural centers and surrounding populations favored the border dynamics in commercial and population terms, as well as organized a mixture of uses that houses in its urban structure, a network of services and commerce along with residential use [24]. Therefore, the railway in Cúcuta, served for the introduction and expansion of technical advances for modern life. In 1892 the city had a telephone plant, in 1896 an electric light plant of the Cúcuta Electric Lighting Company [21]. As well as its influence, it promoted other types of spaces and annex buildings, such as the railway offices in Avenue 6 with 8th street in 1897, international, intermunicipal and municipal stations, of which five lines are named, which led to outline the design of an integrated tram system, reaching $8.7 \mathrm{~km}$ in length, where they worked: the "Cúcuta Station", "Rosetal Station", "National Customs Station", the "Estación Sur o del Puente San Rafael" and to finish the tour, the "Estación Puente Espuma" [25]. This service was offered with four small steam locomotives that dragged three passenger cars, some vans were used for cargo transport, which successfully articulated the system with the railroad of the region [26].

In general the urban scheme is impacted from large scale to small scale with all the complementary services to the railway system, such as those described above, not to mention Commercial House 1916, Luxembourg Warehouse 1920, National Customs control buildings 1919, inspection booths, elevated tanks for storage of locomotive water supply, wharf, fuel zone, repair pit in the workshops of the Railway in the Cúcuta Station, civil works of the elevated railways as the elevated bridge Tatuco route Port Santander, on the border with Venezuela, housing units for technical engineers, hotels such as the prominent Hotel Europa and Hotel Universal, health center, Maternity House 1910, endowment of the Hospital San Juan de Dios 1910 and those of small scale like the railway lines, the changes rails, triangles to change the orientation of the locomotive, scales, cranes, signs of stations, furniture of waiting like chairs and small inns with pronounced covers [27].

Likewise, the architectural typology underwent transformations thought in the big stations and in the handling of a greater number of population, views in wide corridors, pronounced eaves for the protection of the sun, more durable and industrialized materials, and the same facades of the haciendas when transforming their morphology in inexpressive physiognomy of railway stations.

On the other hand, economic investment was a challenge. The necessary costs for the execution of this work were partly obtained from the funds extracted from the $10 \%$ bonds according to the law of 1924 for a value of $\$ 600000$ plus the compensation of the Panama Canal, \$300000 from the national budget and $\$ 500000$ granted by the Congress of 1925 [28]. In correspondence they register in 1926 an exclusive adjudication of $0,26 \%$ of the total of the investments for the railroad in Colombia, ascending annually to $1.07 \%$ in $1927,1.53 \%$ in 1.928 obtaining the highest point in 1930 with $1.71 \%$ of the national investment. These figures harmonize with the growth of the coverage of the networks, so that for 1930 it reaches 100 Kilometers of railroad, that is to say, as it is expected to maximum investment greater indicator of coverage of the railroad system in Cúcuta.

The locomotive was a costly symbol of modernity, empowerment and transformation of the rural and urban profiles that required a vital architectural infrastructure for the technical functioning of the system and coherent with 
territorial development. This infrastructure was favored by the investment from 1926 to 1928 , however, the predictive model of investment I for a time $t$, corresponding to a rational function $(r=0.87)$, shows a decline for future years, which responded to the competitive era of the automobile and policies immersed in the Department's development plan in the 1960s and system readjustment.

$$
\text { Invesment } I=\frac{0.00163+0.0013 t}{1-0,238 t+0.0272 t^{2}}
$$

The accumulated investment (2) of the State to sustain the railroad suggested potential increases whose predictive model for a correlation coefficient of 0.99 was estimated with an inflection point in 1933, a time of greater boom of the railroad industry in the city, but which meant requiring large investments in the sector by government entities for future years, the possibility of non-viable economic scale as it required greater capacity to generate income.

$$
\begin{aligned}
& \text { accumulated investment }= \\
& -0.75+0.91 t+0.55 t^{2}-0.043 t^{3}
\end{aligned}
$$

The exploitation coefficient (EC) reflected gradual growth with peaks in 1937, 1950, it also reflected a level of coverage of expenses by income, correcting the effect in the change of scale. The density of the network fluctuated without variability, cargo traffic did not show a definite trend evidencing reduced variability, and passenger traffic in rural areas and in San José de Cúcuta also showed a drop reflecting a very variable evasion control and benefits granted to low-income passengers in the region from 20 to $40 \%$. This increased the deficit of the railway company, where the ratio of current revenue expenditure was placed in the fifties at a value of 3 [29].

The natural tendency towards the loss of traffic, the development of the paved road system, together with state policies, led to the decline of railways in this region. In 1960, the closure of sections of the network began, its use is concentrated in cargo transport, the personnel plant is affected, increasing its deficient performance and the loss of abandoned machines in the city's outdoors, as well as inspection booths, elevated tanks for storing water to supply the locomotive, wharfs, fuel zone, repair pit in the workshops, among other elements that were gradually dismissed as valuable pieces of urban profiles.

The analysis for econometric adjustment of previous EC correction with tendency to increase, starting from the implementation of actions for the use of freight transport, for a productivity $P$, with a relation with tendency to increase in the sixties, between average salary SM and average traffic TM and their respective indicators of significance and efficiency, variable Dummy for 1970 , given from the relation:

$$
C E=-0.017 P+0.005 \frac{S M}{T M}+0.0229 D
$$

They indicate adequate statistical reliability Statistical DW=1.589 with coefficient of determination $87 \%$, coefficients for $D$ of 0.0229 , error of 0.1 and statistical $t=2$. Ultimately, the railway generated an unprecedented communication network, favoring national unity, but also forging border ties, with greater possibilities for exports, carrying with it the yearning from those times of modernization, competitiveness and vision to the future. I transform the cultural landscape, allowing the interaction of social groups dedicated to different trades, which make economic transformations viable. Undoubtedly this is part of history, as Ruskin noted "it belongs partly to those who built it and partly to all the generations of humanity that will follow us" [29].

\section{CONCLUSIONS}

In Colombia, the railway networks reached a slower coverage of 126 municipalities, crossing 
a fairly irregular relief, however, this system was motivated by economic growth in the first half of the twentieth century, reached by the rapid expansion of coffee remittances. In the same way, with multiple difficulties, the railway system was developed in San José de Cúcuta, the railroad tracks allowed it to form a regional and binational link, consolidating itself as the first city in Colombia to achieve international connection, and the local internal system of railway network. The relationship of the railway system with industry, agricultural centers and surrounding populations favored the border dynamics in commercial and population terms, introducing to the city technological advances for modern urban life, so that the old traditional schemes of residential use are transformed to mixed use with services, commerce and public spaces for more people. Likewise, the architectural typology underwent transformations in terms of profiles inspired by the large stations, so that their facades, even for residential uses, evoked the inexpressive train stations.

The railway had its greatest productivity in the thirties, from this date it begins a potential decline until its closure in the sixties, reflected in the loss of traffic, the required increase in investment for sustainability, the decrease in income, and the operating deficit. The use of freight transport in the 1950s did not reduce the deficit by decreasing productivity, increasing wages and decreasing traffic with the incidence of the automotive boom. Likewise, the urban landscape was affected by the loss of machines abandoned outdoors, as well as other types of infrastructure associated with the railway system, which played an important role at the time, and were gradually forgotten, ignoring their prominence in the History of San José de Cúcuta.

\section{BIBLIOGRAPHIC REFERENCES}

[1] Benevolo L 1987 Historia de la arquitectura moderna (Barcelona: Gustavo Gili)

[2] Balbo J 2008 Guía Práctica para la investigación histórica sin traumas (Venezuela: Fondo editorial UNET)

[3] Sousa V, Driessnack M y Costa I 2007 Revisión de diseños de investigación resaltantes para enfermería: diseños de investigación cuantitativa. Revista Latino-am Enfermagem 15 3

[4] Creswell J W 2003 Research design: qualitative, quantitative, and mixed methods approaches (Thousand Oaks: Sage Publications)

[5] Dermikan H, Spoher J \& Krishna V 2011 Service System Implementation (New York: Springer Publishing)

[6] Ortega-SierraA, Vergel-Ortega, M y RojasSuárez J P 2019 Microenseñanza en cálculo vectorial: su impacto desde un enfoque basado en competencias (Bogotá: Ecoe Ediciones)

[7] Delgado A, Leonor E y Forero-Aponte C 2004 Estado del arte de las investigaciones sobre factores psicológicos en la cultura organizacional, realizadas en facultades de psicología de Bogotá adscritas a ASCOFAPSI (1998 -2003) Revista Acta Colombiana de Psicología 1186.

[8] Hoyos Botero C 2000 Un modelo para la investigación documental. Guía TeóricoPráctica sobre Construcción de Estados del Arte con importantes reflexiones sobre la investigación, (Medellín: Señal Editora).

[9] Fernández Sierra M 2008 El proceso investigativo en el estado del arte de la Maestría en Educación de la Universidad Santo Tomás Magistro 2 107-112.

[10] Strauss A y Corbin J 2002 Bases de la investigación cualitativa. Técnicas 
y procedimientos para desarrollar teoría fundamentada. (Medellín: Editorial Universidad de Antioquia).

[11] Vergel M 2008 Seis sigma en la gestión de Vicerrectoria de bienestar universitario (Caracas: Universidad Pedagógica Experimental Libertador)

[12] Posada-González N 2011Aplicabilidad del estado del arte de Carlos Cardona Pescador en Filosofía, Antropología, Ética y Bioética Revista Persona y Bioética 1569

[13] Parra H, Suarez J and Vergel M 2019 Curricular trends in the University Francisco de Paula Santander academic program offerings Journal of Physics: Conference Series 1329 012013

[14] Lloga R 2016 La labor de los ingenieros militares en los ferrocarriles de Cuba (18371898). Arquitectura y Urbanismo 37397

[15] Nieto C 2011 El ferrocarril en Colombia, la búsqueda de un país Apuntes 2468

[16] Horna H $1994 \quad$ Ferrocarriles latinoamericanos del siglo diecinueve y los casos del Perú y Colombia. Ibero Americana, Nordic Journal of Latin American Studies 2440

[17] Bruner J 2005 Cultural Psychology and its Functions Constructivism in the Human Sciences 1061 .

[18] Cadena C y Silva C 2016 Determinación de la capacidad ferroviaria del corredor Facatativá - Bogotá con sus características físicas actuales. (Bogotá: Universidad Católica de Colombia)

[19] Meisel A, Ramírez M y Jaramillo 2014 Cuadernos de Historia Económica y Empresarial. (Cartagena: Banco de la República)

[20] Correa J 2013 Café y transporte en Colombia: el ferrocarril de Cúcuta. Revista de Economía Institucional 15230
[21] Caicedo J 1991 Vida, pasión y muerte del ferrocarril de Cúcuta. (Cúcuta: Cámara de comercio)

[22] Márquez M 2010 El café eje de una economía agroexportadora ¿dinamizante del crecimiento económico, social y urbano en la depresión del Táchira?. Arquitectura y sociedad. Materiales de investigación (San Cristóbal: Universidad Nacional Experimental del Táchira)

[23] Arias G 2006 La segunda mula de hierro (Bogotá:Panamericana. Formas e Impresos)

[24] Ardao A 1984 El café y las ciudades en los andes venezolanos (1870-1930). Biblioteca de la Academia Nacional de la Historia (Caracas: Italgráfica).

[25] Pabón S 2012 Creación y divulgación de contenidos pedagógicos críticos sobre la historia e identidad regional cucuteña. Cuaderno octavo: los rieles de la ciudad (Cúcuta: Academia de Historia).

[26] De Fusco R 1992 Historia de la Arquitectura contemporánea. (Madrid: Celeste Ediciones.

[27] Tellez G 1958 Critica \& Imagen (Colombia:Editorial Escala)

[28] Caicedo J 1991 Vida, pasión y muerte del ferrocarril de Cúcuta (Cúcuta: Cámara de comercio).

[29] Izard M 1972 La agricultura venezolana en una época de transición (Caracas: Academia de Hisrtoria) 